\title{
Zenei nevelés KovÁszna ÉS HARgitA MEgYE MAGYAR TANNYELVÜ ELEMI OSZTÁLYAIBAN
}

\author{
BARTALIS IZABELLA \\ Debreceni Egyetem BTK Humán Tudományok Doktori Iskola, \\ Nevelés és Müvelődéstudományi Program \\ Beérkezett: 2021. január 26., elfogadva: 2021. november 26.
}

\begin{abstract}
Napjainkban a társadalom a müvészeti nevelést az iskolai rendszerben történő müveltség elsajátításával hozza párhuzamba. Ennek értelmében olyan zenei készségek és képességek fejlesztését szükséges megvalósítani az iskola keretei között, amely hatással van a személyiség komplex fejlődésére. Jelen tanulmány a Kovászna és Hargita megyei magyar tannyelvü osztályaiban történő zenei nevelés fontosságára és a zene- és mozgástantervek hatékonyságára reflektál tanítók körében végzett kvalitatív és kvantitatív kutatások alapján. Eredményeink szerint a 2013/14-es tanévben megjelenő zene- és mozgástanterv pozitívan függ össze az iskolai zenei neveléssel. A mozgás bevezetésével a pedagógusok erőteljesebb hangsúlyt fektettek a népi gyermekjátékok és a néptánc oktatására.
\end{abstract}

Kulcsszavakः curriculum, zenei nevelés, zene- és mozgástanterv

Nowadays society parallels Arts Education with the acquirement of learning within the framework of the curriculum, in other words in a school system. Consequently, it is necessary to develop those musical skills and abilities within the school that have a beneficial effect on the complex growth of the person. This present study reflects the importance of music education in Kovászna and Hargita counties in Hungarian classes and the effectiveness of music and movement curricula through qualitative and quantitative research made among teachers. Our results show that the new music and movement curriculum is associated with musical education in schools. Including movement into the lessons, teachers place even more emphasis on teaching popular games and folk dance.

Keywords $¥$ curriculum, musical education, music and movement curriculum

Levelező szerző: Bartalis Izabella, 535600 Székelyudvarhely, II. Rákóczi Ferenc utca, 19/9.

E-mail: izabellabartalis2018@gmail.com 


\section{Bevezetés}

$\mathrm{A}$ zenei nevelés pozitív hatására számos zenepedagógiai szakirodalmi forrás utal, kutatási eredmények bizonyítják a zene fejlesztő hatását minden korosztályban (Kiss 2010; Mark 2002; Shouldice 2013; Szücs 2017; Váradi 2017). Az iskolai zenei nevelés hozzájárul a személyes és szociális kompetenciák fejlődéséhez, valamint a zeneértő, zeneszerető generációk kineveléséhez. A formális rendszerben történő zenei nevelés a romániai magyar elemi osztályokban a Zene és mozgás tantárgy keretében valósul meg, de mindezek mellett integráltan több tantárgyon belül is alkalmazható, például a hangulati előkészítés, a tananyag tartalmi ismereteinek bővítése céljából, stresszt oldó eszközként, vagy idegen nyelvek elsajátításánál. A 2011-es romániai Tanügyi Törvényben meghatározott, a 2013/14-es tanévtől bevezetett zeneés mozgáskerettanterv két ciklusban tárgyalja az elemi osztályok ének-zene- és mozgásórák kompetenciáit, ennek értelmében az elemi oktatás előkészítő, 1. és 2. évfolyamain hetente két zene- és mozgásóra van, amely a 3. és 4. évfolyamokon heti egy órára csökken. A második óra helyét átveszi egy játék-mozgás elnevezésű tantárgy.

A zene- és mozgástanterv sikerességére vagy esetleges hiányosságaira irányuló kutatás ez idáig nem jelent meg a szakirodalomban. Ezért jelen tanulmányunk célja a kurrikuláris zenei nevelés fontosságának és a zene- és mozgástantervvel kapcsolatos pedagógusvélemények feltérképezése, Kovászna és Hargita megyei magyar tannyelvű elemi osztályaiban tanító tanítók körében folytatott kvalitatív és kvantitatív vizsgálatok segítségével. Kutatásunk céljának megfelelően az alábbi két kérdésre kerestük a választ: 1) Hogyan látják a zenei nevelés fontosságát a Kovászna és Hargita megye elemi iskoláinak alsó tagozatán tanító pedagógusok? 2) Hogyan biztosítják az elemi iskola zeneés mozgástantervei a zenei nevelés megvalósulásának lehetőségeit?

\section{A kutatásról}

Kvalitatív előkutatásunkban a tanítók zenei neveléssel és a zene- és mozgástantervvel kapcsolatos véleményeket gyüjtöttük össze. Az interjúkat 2018 decemberében vettük fel, amelyek során öt, Kovászna vagy Hargita megye elemi osztályokban tanító pedagógust kérdeztünk, akik már több mint egy évtizedes gyakorlattal rendelkeznek. A legalább egy évtizedes gyakorlati tapasztalatot azért tartottuk fontosnak az interjúalanyok kiválasztásánál, mert ők a gyakorlatukból adódóan ismerik a régi és a 2013/14-es tanévben megjelent új zene- és mozgástantervet is.

Ezt követően papíralapú kérdőíves felmérést terveztünk a Kovászna és Hargita megyei magyar tannyelvű elemi osztályokban tanító pedagógusok körében, azonban a COVID-19-világjárványra reagáló, 2020 januárjában megjelenő román törvények értelmében tilos lett papíralapú dokumentumokat kézbesíteni. Ennek következtében online kérdőíves felmérésre álltunk át, és a kérdőívet Google forms dokumentumként juttattuk el a célcsoporthoz. Az így kiküldött kérdőívünket mindösszesen 78 pedagógus töltötte ki. A visszaérkezett válaszok alacsony számában minden bizonnyal a járványhelyzet is éreztette hatását, mivel az online oktatásra történő átállás növelte a pedagógusok többletterheit, nehézségeit. A válaszolók túlnyomó többsége $(98,7 \%)$ nő, mely jól jelzi a tanítói szakma elnőiesedését. A válaszadók 52,6\%-a Hargita megyében és 
47,4\%-a Kovászna megyében tanít. A falun tanítók 65,4\%-ban, míg a városban tanítók 34,4\%-ban képviseltetik magukat a mintában.

\section{A kutatás eredményei}

\section{A zenei nevelés fontosságának megítélése}

A zenei nevelésnek egy közösségen belül összetartó szerepe van. A közös éneklés, zenélés és játék öröme képes az osztályközösségek megerősítésére, a kedvezőtlen szociokulturális különbségek tompítására, a konfliktusos helyzetek által generált feszült hangulat feloldására (Árvayné 2012; Szücs 2017).

Első kutatási kérdésünkben arra kerestük a választ, hogy a Kovászna és Hargita megye elemi osztályaiban tanító pedagógusok milyen fontosságot tulajdonítanak a zenei nevelésnek. A kvantitatív vizsgálatunkhoz használt kérdőívben az erre vonatkozó kérdés 16 állítást tartalmazott, amelyhez egy 1-től 5-ig terjedő Likert-skálát társítottunk, ahol az 1-es jelentette azt, hogy a megkérdezett egyáltalán nem ért egyet, az 5-ös pedig azt, hogy teljes mértékben egyetért az állítással. Az állítások mögött különböző válaszokat feltételeztünk, melyet a faktoranalízis főkomponens módszerének segítségével ellenőriztünk. Az elemzés során három faktor (1. ZK: zene komplex hatásai, 2. ZTP: zene mint terápiás, prevenciós eszköz és 3. ZI: zenei ismeretek bővítése) rajzolódott ki (KaiserMeyer-Olkin-mutató: 0,898; megmagyarázott variancia: 73,7\%). A faktorelemzés során azokat az itemeket tekintettük egy faktorba tartozónak, melyeknek faktorsúlya elérte a 0,5-ös értéket. Azokat az itemeket, melyek ez alapján több faktorhoz is tartoztak, kizártuk a faktorelemzésből. Továbbá kizártuk az elemzésből a „Nincs hatással a tanulók magatartására" állítást is, mivel ez az item egyedül alkotott egy faktort.

Az első, „zene komplex hatásai” faktorba azok az állítások tartoznak, amelyek a zenei nevelést a személyiség komplex fejlesztéseként értékelik. A szakirodalom is kiemeli, hogy a zene a transzferhatásai révén képes a kognitív, szociális és érzelmi intelligencia mellett az egyén önértékelését, önbizalmát, önkritikáját is egyaránt fejleszteni (Bresler 2002; Kiss 2010; Szücs 2017). A második, „zene, mint terápiás, prevenciós eszköz” faktort azok az állítások alkotják, amelyek a zenei nevelésben a tanulási kudarcokat megelőző lehetőséget látják. Vannak olyan kutatási eredmények, amelyek a zenének az idegrendszerre, a testi és lelki egészségre való pozitív hatását igazolják (Uzsalyné 2008). A harmadik, „zenei ismeretek bővítése" faktorba azok az állítások tartoznak, amelyek a népzenei, klasszikus zenei ismeretek bővítésének lehetőségét ismerik fel a zenei nevelés folyamatában (1. táblázat).

1. táblázat: A zenei nevelés fontosságának értékelése, faktoranalízis

\begin{tabular}{lccc}
\hline & \multicolumn{3}{c}{ Faktorok } \\
\cline { 2 - 3 } Állítások & $\begin{array}{c}\text { 1. ZK: zene } \\
\text { komplex hatásai }\end{array}$ & $\begin{array}{c}\text { 2.ZTP: A zene mint terá- } \\
\text { piás, prevenciós eszköz }\end{array}$ & $\begin{array}{c}\text { 3. ZI: A zenei } \\
\text { ismeretek bővítése }\end{array}$ \\
\hline $\begin{array}{l}\text { Hozzájárul a zeneszerető- és } \\
\text {-értő tanulók neveléséhez }\end{array}$ & 0,855 & \\
$\begin{array}{l}\text { Felkelti a zene iránti } \\
\text { érdeklődést }\end{array}$ & 0,812 & \\
\hline
\end{tabular}


1. táblázat: (folyt.)

\begin{tabular}{|c|c|c|c|}
\hline \multirow[b]{2}{*}{ Állítások } & \multicolumn{3}{|c|}{ Faktorok } \\
\hline & $\begin{array}{l}\text { 1. ZK: zene } \\
\text { komplex hatásai }\end{array}$ & $\begin{array}{l}\text { 2. ZTP: A zene mint terá- } \\
\text { piás, prevenciós eszköz }\end{array}$ & $\begin{array}{l}\text { 3. ZI: A zenei } \\
\text { ismeretek bővítése }\end{array}$ \\
\hline $\begin{array}{l}\text { Zeneszerető és -értő tanulók } \\
\text { nevelése }\end{array}$ & 0,766 & & \\
\hline $\begin{array}{l}\text { Szerepe van a tehetséggondo- } \\
\text { zásban }\end{array}$ & 0,765 & & \\
\hline Fejleszti a kreativitást & 0,651 & & \\
\hline $\begin{array}{l}\text { Befolyásolja a gyermekek } \\
\text { érzelmi fejlődését }\end{array}$ & 0,566 & & \\
\hline $\begin{array}{l}\text { Megerősíti az önbizalmat/ } \\
\text { onértékelést }\end{array}$ & 0,536 & & \\
\hline $\begin{array}{l}\text { Megerősíti a társas kapcso- } \\
\text { latokat, közösségformáló } \\
\text { hatása van }\end{array}$ & 0,500 & & \\
\hline $\begin{array}{l}\text { Lehetőséget ad a tanulási } \\
\text { kudarcok kialakulásának } \\
\text { megelőzésére }\end{array}$ & & 0,852 & \\
\hline Segíti a tanulók megismerését & & 0,768 & \\
\hline Bővíti a népzenei ismereteket & & & 0,860 \\
\hline $\begin{array}{l}\text { Hozzájárul a klasszikus zenei } \\
\text { alkotások megismeréséhez }\end{array}$ & & & 0,802 \\
\hline
\end{tabular}

Megjegyzés: Faktorelemzés: Principal component módszer, Varimax rotálás.

Forrás: Saját adatfelvétel

$\mathrm{A} z$ adatbázis alacsony elemszáma miatt az eredményeket fenntartásokkal érdemes kezelni. Ezért kiegészítő információként megnéztük az egyes állításokra adott átlagok és szórások értékeit is. A 2. táblázatból látható, hogy a tanítók véleménye a zenei nevelésről minden állításnál négyes fölötti, nagyon jó értéket mutat. Kivéve a „Nincs hatással a tanulók magatartására” állítást, amellyel egyáltalán nem értenek egyet a válaszadók. Tehát összességében elmondhatjuk, hogy a pedagógusok a zenei nevelésnek elsősorban pozitív hatást tulajdonítanak.

$\mathrm{A} z$ interjúk is alátámasztják ezt az eredményt. A megkérdezett pedagógusok közül az 1. interjúalanyunkat a zenét komplex vonatkozásban értékelők csoportjába sorolhatjuk, mivel válaszában kiemeli a zene sokoldalú, személyiségfejlesztő hatásának, transzferhatásának fontosságát.

„Rengeteg készséget zenélés közben használunk, igy zene által készségeket is fejlesztünk. A zenei nevelés a teljes személyiség fejlödésére hatással van. A mindennapi zenei nevelés rendkivüli jó hatással van a kreativitás fejlödésére. [...] A zene különbözö erkölcsi tulajdonságokat erösít a gyermekben, mint pl. együttérzés, igazságosság, kitartás, szorgalom, önfegyelem, figyelmesség, segitökészség." (1. interjúalany) 
2. táblázat: A zenei nevelés állításainak átlaga és szórása

\begin{tabular}{llcc}
\hline Faktor & \multicolumn{1}{c}{ Állítások } & Átlag & Szórás \\
\hline ZK & Megerősíti a társas kapcsolatokat, közösségformáló hatása van. & 4,80 & 0,428 \\
ZK & Befolyásolja a gyermekek érzelmi fejlődését. & 4,79 & 0,930 \\
ZK & Hozzájárul a zeneszerető, zeneértő személyiség kialakításához. & 4,86 & 0,593 \\
- & Segít a gyermekek lelki feszültségeinek feloldásában. & 4,65 & 0,661 \\
ZK & Fejleszti a kreativitást. & 4,65 & 0,647 \\
- & Segíti a szabadidős tevékenységek zenével való kitöltését. & 4,64 & 0,582 \\
ZK & Megerősíti az önbizalmat/önértékelést. & 4,63 & 0,605 \\
ZK & Felkelti a zene iránti érdeklődést. & 4,61 & 0,631 \\
ZK & Szerepe van a tehetséggondozásban. & 4,61 & 0,671 \\
ZI & Bővíti a népzenei ismereteket. & 4,60 & 0,691 \\
ZK & Zeneszerető és -értő tanulók nevelése. & 4,59 & 0,612 \\
ZTP & Lehetőséget ad a tanulási kudarcok kialakulásának megelőzésére. & 4,33 & 0,862 \\
ZI & Hozzájárul a klasszikus zenei alkotások megismeréséhez. & 4,30 & 0,924 \\
& A szociális különbségeket kiegyenlítő, hátránykompenzáló & 4,24 & 0,875 \\
- & szerepe van. & 4,24 & 0,845 \\
ZTP & Segíti a tanulók megismerését. & 1,62 & 1,207 \\
\hline & Nincs hatással a tanulók magatartására. & &
\end{tabular}

Megjegyzés: ZK: zene komplex hatásai; ZI: zenei ismeretek bővítése; ZTP: zene mint terápiás, prevenciós eszköz.

Forrás: Saját adatfelvétel

A második faktor állításait emeli ki a 2. interjúalany, aki a zenei, valamint az esztétikai készségek fejlesztését látja elsődlegesen megvalósulni a zenei nevelés folyamatában.

„A minöségi zenei oktatásnak több területen fejlesztő hatása van. Növeli a tanulók szépérzékét, ritmusérzékét, koncentrációját, több dologra való összpontositási készségét, belsö ballását, memóriáját." (2. interjúalany)

Összességében elmondható, hogy a Kovászna és Hargita megye elemi iskoláiban tanítók válaszai arra utalnak, hogy a zenei nevelést a komplex személyiség fejlesztésére alkalmasnak értékelik, kiemelve annak terápiás, prevenciós jellegét.

\section{A zene-és mozgástantervek hatékonyságának megitélése}

A zenei nevelés céljainak elérése érdekében meghatározó szerepe van a zenét tanító pedagógus személyiségének, zene iránti elkötelezettségének, a zenei ismeret mellett, a zenei 
nevelés tartalmát, célkitűzéseit, tananyagát magába foglaló dokumentum, a zene tantárgy tantervének ismeretére.

A romániai elemi osztályok zenei nevelés tantárgya a zene és mozgás, amelynek az alapdokumentuma a 2013/14-es tanévben megjelenő tanterv. A zene- és mozgástantervvel kapcsolatos vizsgálatunkban elsősorban arra kerestük a választ, hogy a tanítóknak mi a véleményük a tanterv tartalmáról, felépítéséről, nyelvezetéről, alkalmazhatóságáról. A kérdőívben a zene- és mozgástantervvel kapcsolatosan 14 állítást fogalmaztunk meg, amelyre egy 1-től 5-ig terjedő Likert-skálán fogalmazhatták meg a véleményüket ( 1 = egyáltalán nem ért egyet, 5 = teljes mértékben egyetért). A $z$ állításokat faktoranalízis (főkomponens módszer) alapján két csoportba rendeztük (Kaiser-Meyer-Olkinmutató: 0,863; megmagyarázott variancia: 68,9\%). A faktorelemzés során azokat az itemeket tekintettük egy faktorba tartozónak, melyeknek faktorsúlya elérte a 0,5-es értéket. Azokat az itemeket, melyek ez alapján több faktorhoz is tartoztak, kizártuk a faktorelemzésből.

Az első, „gyermekcentrikus tanterv” elnevezésű faktorba azok az állítások sorolódtak, amelyek a tantervet a tanulók szempontjából értékelték, fontosságot tulajdonítva az interdiszciplinaritásnak, a módszerek szabad választásának és - a mozgásos játékok bevezetésével - a zene élményszerű oktatásának. Ezenfelül a faktor magába foglalja a tan-

3, táblázat: A zene- és mozgástanterv értékelése - faktoranalízis

\begin{tabular}{lcc}
\hline & \multicolumn{2}{c}{ Faktorok } \\
\cline { 2 - 3 } Állítások & $\begin{array}{c}\text { GYCT: gyermek- } \\
\text { centrikus tanterv }\end{array}$ & $\begin{array}{c}\text { SZT: szakszerü } \\
\text { tanterv }\end{array}$ \\
\hline $\begin{array}{l}\text { Teret ad a tanítónak a módszerek, eljárások } \\
\text { használatának szabadon választásában. }\end{array}$ & 0,848 \\
Lehetőséget nyújt a tantárgyak közötti szerves & 0,806 \\
kapcsolódás kialakulására. & 0,760 \\
Előnyben részesíti a mozgásos tevékenységeket. & 0,741 \\
Életkori sajátosságoknak megfelelően felépített. & 0,733 \\
Könnyen alkalmazható. & 0,716 \\
Nyelvezete érthető, világos. & 0,572 \\
A tananyag spirálisan egymásra épül évfolyamonként. & & \\
A javasolt zenehallgatási anyag megfelelő. & & 0,815 \\
A javasolt dalanyag megfelelő. & & 0,805 \\
A zene élményszerű oktatására törekszik. & 0,778 \\
Alkalmas a zenei kreativitás fejlesztésére. & & 0,774 \\
Biztosítja a zeneértővé nevelést. & & 0,703 \\
\hline
\end{tabular}

Megjegyzés: Faktorelemzés: Principal component módszer, Varimax rotálás.

Forrás: Saját adatfelvétel 
terv életkori sajátosságainak megfelelő felépítettségét is. A második, „szakszerű tanterv” faktorban azok az állítások jelennek meg, amelyek a megfelelő dallam, ritmus és zenehallgatási anyag mellett, a zeneértővé nevelés és a kreativitás fejlesztése szempontjából is hatékonynak értékelik a tantervet (3. táblázat).

A tanterv gyermekcentrikusságáról az interjúalanyok is beszámoltak, kiemelve az életkori sajátosságokhoz való igazodást, valamint a zene- és a mozgástantervben történő összekapcsolódását.

„Az új tanterv tartalmi szempontból tömör, nehézségi foka megfelel a gyermekek életkori sajátosságainak. [...] A gyermekek nagy mozgásigénnyel rendelkeznek, ezért jó ötletnek tartom, bogy a két tantárgy összeillesztödött, abol a változatos, érdekes, értékes népi gyermekjátékok is nagy teret kaptak." (3. interjúalany)

Az előzőekhez hasonlóan a tanterv megítélése kapcsán is megvizsgáltuk az egyes állítások átlagát és szórását. Amint a 4. táblázatban is látható, a tantervvel kapcsolatos állítások alapvetően jó értékelést kaptak. Az eredményekből kitűnik, hogy a zene mozgással való párosítását a tanítók pozitívan értékelik. A zeneértővé nevelés a zenei nevelés

4. táblázat: A tantervvel kapcsolatos állítások átlaga és szórása

\begin{tabular}{|c|c|c|c|}
\hline Faktorok & Állítások & Átlag & Szórás \\
\hline GYCT & $\begin{array}{l}\text { Teret ad a tanítónak a módszerek, eljárások használatának } \\
\text { szabadon választásában. }\end{array}$ & 4,23 & 0,856 \\
\hline GYCT & Előnyben részesíti a mozgásos tevékenységeket. & 4,06 & 0,902 \\
\hline GYCT & Életkori sajátosságoknak megfelelően felépített. & 4,01 & 0,904 \\
\hline SZT & A zene élményszerű oktatására törekszik. & 3,93 & 0,907 \\
\hline- & A dallamkészségek fejlesztésére alkalmas. & 3,90 & 0,905 \\
\hline GYCT & A tananyag évfolyamonként spirálisan egymásra épül. & 3,88 & 0,931 \\
\hline GYCT & $\begin{array}{l}\text { Lehetőséget nyújt a tantárgyak közötti szerves kapcsolódás } \\
\text { kialakításában. }\end{array}$ & 3,88 & 0,939 \\
\hline- & $\begin{array}{l}\text { Szakszerűen felépített a ritmuskészség fejlesztésének szem- } \\
\text { pontjából. }\end{array}$ & 3,85 & 0,948 \\
\hline SZT & A javasolt zenehallgatási anyag megfelelő. & 3,85 & 0,854 \\
\hline GYCT & Nyelvezete érthető, világos. & 3,82 & 0,848 \\
\hline GYCT & Könnyen alkalmazható. & 3,76 & 0,896 \\
\hline SZT & Alkalmas a zenei kreativitás fejlesztésére. & 3,73 & 1,050 \\
\hline SZT & A javasolt dalanyag megfelelő. & 3,71 & 0,929 \\
\hline SZT & Biztosítja a zeneértővé nevelést. & 3,50 & 1,071 \\
\hline
\end{tabular}

Megjegyzés: GYCT: gyermekcentrikus tanterv; SZT: szakszerü tanterv

Forrás: Saját adatfelvétel 
egyik legfontosabb célkitűzése (Váradi 2010), így törekednünk kell arra, hogy a tantervben, valamint a zene- és mozgásórák keretében is központi helyet foglaljon el. Ugyanakkor az erre vonatkozó állítások kapcsán lényegesen kisebb átlagértékek jelennek meg, mint a zenei nevelésre vonatkozó állításoknál.

A tanítókkal készült interjúkban arra is választ kerestünk, hogy a 2013/14-es tanévben megjelenő zene- és mozgástanterv milyen újdonságokat hozott a zenei nevelés folyamatába. A megkérdezettek pozitív elmozdulásnak tekintették a zene-mozgás órákat, amelyek így eleget tesznek az elemi osztályos tanulók mozgásigényének, érdekesebbé, változatosabbá téve az énekórákat.

„Rugalmas, gyermekközelibb, élményközpontú, nagyobb teret biztosit az ismétlésre, elmélyitésre, egyéni éneklésre ösztönzésre, a mozgásos tevékenységeknek, széles ének-zene tárházat nyújt a pedagógusnak." (1. interjúalany)

„Az új típusú zene-mozgás órák a játékosságra kell, hogy épüljenek alsó tagozaton. Jelentös szerepet kap az élményszerzés, mivel eltérő a gyermekek éneklési készsége vagy mozgáskoordinációjuk fejlettsége. Nem az ismeretek átadása révén valósul meg a készségfejlesztés, hanem élményszerzés által. A kicsiknek óriási a mozgásigénye, melyet remekül kihasználbatunk a gyermekjátékok, az énekes mesék elöadásával, vagy a tanitó által kitalált ritmikus, dallami, hallási (zenehallgatási) feladatokkal. Ezáltal az alapozó munka, a zene megszerettetése, a dallami, ritmikai, hallási fejlesztés kiváló alapokat kaphat." (5. interjúalany)

A 2013/2014-es tanévben megjelent tantervvel bevezetett játék és mozgás, illetve a zene- és mozgásórák, sok év tapasztalattal rendelkező pedagógusoknak is élményszerü tevékenységet jelentenek. Minden újabb generációval olyan gyermekek jönnek az iskolába, akiknek alapigényük a mozgás, a mozgásos játék, a ritmikus mondóka. Az elmondottak alapján azt is megállapíthatjuk, hogy a tanítók többsége a zene- és mozgásórán, mozgásként a gyermekdalok és a néptánc adta lehetőségeket aknázza ki, viszont vannak pedagógusok, akik az egyik zene- és mozgásórájukat tánctanárra bízzák.

\section{Összegzés}

Tanulmányunkban a 2013/14-es tanévben megjelenő, romániai magyar elemi osztályok számára kidolgozott zene- és mozgástantervekkel kapcsolatos tanítói vélemények feltárására vállalkoztunk Kovászna vagy Hargita megyei tanítók körében végzett online kérdőíves felmérés, illetve interjúk segítségével. A Romániában élő magyarok zene- és mozgástanterve hangsúlyozza a mozgás és a ritmushangszerek fontosságát a romániai elvek alapján, a dalanyagát a magyar gyermekdalok és gyermekjátékok világából meríti és zenepedagógiai elveit tekintve követi a magyar koncepciókat. A tantervek alkalmazkodnak a román zenetantervi elöírásokhoz, ragaszkodva a nemzeti identitásukat megőrző magyar zenei anyanyelvet használó koncepciókhoz.

$\mathrm{A} z$ interjúk és a kérdőíves felmérés eredményei egyaránt azt jelzik, hogy a bevezetett zene- és mozgástantervekről alapvetően jó véleménnyel vannak a tanítók. Hozzátéve, hogy véleményük szerint a zenei nevelés céljaként szolgáló zeneértővé nevelés fontossága a legkevésbé érvényesül a tervekben. Válaszaik alapján kiemelten a gyermekközpontú- 
ság és a szakszerű tananyag kiválasztása jellemzi a zene- és mozgástantervet. A kutatás alapvető korlátja a kis mintaelemszám, valamint az is, hogy a válaszadó pedagógusok a társadalom és a pedagógiai szakma által elvárt megfelelés igényéből választották ki az állításaikat és nem a saját attitűdjeik alapján. Éppen ezért a továbbiakban szükségesnek látjuk a kutatásban részt vevő Kovászna és Hargita megyei tanítók számának emelését.

\section{IRODALOM}

Árvayné Nezvald A. (2012) A zenei nevelés transzferhatási csecsemő- és kisgyermekkorban. http://trainingandpractice.hu/?q=hu/kepzes_es_gyakorlat/content/226162434 [Letöltve: 2020. 10.22.]

Bresler, L. (2002) Research: A Foundation for Arts Education Advocacy. In: The New Handbook of Research on Music Teaching And Learning. Oxford, Oxford University Press. pp. 1066-1083.

KIss V. (2010) Művészeti nevelés, művészettel nevelés, művészetterápia. Iskolakultúra, Vol. 20. No. 10. pp. 18-31. http://real.mtak.hu/57898/ [Letöltve: 2020. 05. 24.]

Mark, M. L. (2002) Outcomes of Music Education. In: Colwell, R. \& Richardson, C. (eds) The New Handbook of Research on Music Teaching and Learning. Oxford, Oxford University Press. pp. 1042-1083.

Shouldice, H. N. (2013) One Elementary Music Teacher's Beliefs about Musical Ability: Connections to Teaching Practice and Classroom Culture. Dissertacion. Michigan State University. https://www.academia.edu/5681640/One_Elementary_Music_Teachers_ Beliefs_About_Musical_Ability_Connections_to_Teaching_Practice_and_ Classroom_Culturen [Letöltve: 2020. 04. 12.]

Szűcs T. (2017) A zenetanulás társadalmi hatásai. In: VÁradi J. \& Szứcs T. (eds) Sokszinü zenepedagógia. Debrecen, Debreceni Egyetemi Kiadó. pp. 3-17.

Uzsalyné DR. PÉCSI R. (2008) Azérzelmi intelligencia fejlesztése zenével. Egy zenei nevelési koncepció bemutatása. Doktori disszertáció. Jyvaskyla - Pécs. http://disszertacio.unieszterhazy.hu/34/1/\%C3\%A9rtekez\%C3\%A9s\%20magyar.pdf [Letöltve: 2020. 11. 12.]

VÁradi J. (2010) Hogyan neveljünk értő közönséget a komolyzenének? Doktori disszertáció. Universty of Jyvaskyla. https://jyx.jyu.fi/bitstream/handle/123456789/24968/ 9789513938987.pdf?sequence $=1$ [Letöltve: 2020. 01. 28.]

VÁRADI J. (2017) A nonformális zenei nevelés integrálásának lehetőségei a formális oktatásba. In: VÁradi J. \& Szücs T. (eds) Sokszinü zenepedagógia. Debrecen, Debreceni Egyetemi Kiadó, pp. 73-85.

A cikk a Creative Commons Attribution 4.0 International License (https://creativecommons.org/licenses/ by/4.0/) feltételei szerint publikált Open Access közlemény, melynek szellemében a cikk bármilyen médiumban szabadon felhasználható, megosztható és újraközölhető, feltéve, hogy az eredeti szerző és a közlés helye, illetve a CC License linkje és az esetlegesen végrehajtott módosítások feltüntetésre kerülnek. (SID_1) 